\section{Analyzing the costs of military engagement}

\section{Olaf J. de Groot}

$\mathrm{C}$ onflict is costly. While few will reject this statement, it is also an ambiguous one. Does it refer for instance to the economic impact of conflict or to the actual cost of going to war? The former has been the subject of several studies, particularly in the recent past, while the latter has received relatively little attention. ${ }^{1}$

This article focuses on the second type of analysis, and especially on the budgetary impact of going to war. In a time of increasing calls for transparency and government accountability, one would expect that the issue of war expenditure should be high on the public agenda. Unfortunately, this is not necessarily the case. The widely discussed work by Linda Bilmes and Joseph Stiglitz highlights that governments can significantly underreport their own costs when it comes to specific military engagements. This differs from the data situation on military expenditure in general, which is more broadly and more reliably available due to continuous efforts made at the Stockholm International Peace Research Institute (SIPRI) which has developed a uniform methodology to produce internationally comparable data on military expenditure. ${ }^{2}$

The next section describes various actors with different legitimate claims to transparent information on the budgetary cost of conflict. This is followed by an overview of the existing literature on conflict cost analysis, the description of a methodology for approaching the issue of budgetary transparency, and an elaboration on the particular challenges for executing such analyses. The final section concludes.

The interests and priorities of different stakeholders

Even though their priorities and membership overlap, researchers, government, and the public-at-large constitute the three main interest groups with respect to the analysis of conflict costs. Researchers want objective information and the ability to conduct comparative studies across regions and time. Governments can benefit from additional knowledge to improve future decisionmaking but they may also feel threatened by increased transparency if it were to expose weak decisionmaking in the past. Voters benefit from transparency by being enabled to hold policymakers accountable and, since tax monies are being spent, the public also has a wider moral claim to the right to know the cost of war.

\section{Researchers}

The objectives of researchers are very specific as their utility functions are largely controlled by their research output. But conducting a budgetary analysis of conflict specifically can yield research output that is also both of intrinsic scientific interest and that may create considerable media attention. Examples are the publication of Joseph Stiglitz and Linda Bilmes' account of the cost of the United States' wars in Iraq and Afghanistan and the estimates by Tilman Brück, Olaf J. de Groot, and Friedich Schneider on the cost of Germany's involvement in Afghanistan. ${ }^{3}$

Increasing the amount of information available across countries and conflicts not only improves data comparability but also improves researchers' capacity to provide useful and reliable policy advice. The kind of policy advice that can be generated on the basis of better data can affect both the conduct in ongoing military ventures as well as participation in future conflicts. Even an ideologically-driven researcher advocating peace should be able to benefit from evidence-based research that is able to convince politicians and the public alike.

It is also important to be able to point out to policymakers what the challenges are in conducting such research. As discussed later, the greatest challenge is the lack of transparency and accountability in government expenditure. This issue and the accompanying unavailability of much of the necessary data indicate a greater problem in society, and it is a moral imperative for researchers to point out that such a gap exists.

Finally, if war and the costs to all its participants were fully analyzed, this would extend SIPRI's work by moving from country-based military expenditure to war-based military expenditure. Presently, reasonable data may be available to compare the expenditure of, say, China and the United States, but this data cannot be used to compare the costs of, for example, the wars in Iraq and Afghanistan. Being able to do so may result in new insights about the burden of military expenditure. It may even allow for the possibility of performing cost-benefit analyses on conflicts that truly take into account the entire breadth of costs.

\section{Governments}

For governments, war-cost analyses are valuable as well, but for different reasons. In general, decisions to go to war are not made on the basis of cost-benefit analysis, even though they probably should be. Looking at past decisions is not helpful for politicians since these decisions can no longer be changed. Furthermore, the public may be alarmed to learn about previous weak decisionmaking and increase any existing doubt about the quality of current policymakers. But if any lessons learned 
help to improve conflict cost forecasting, this can be valuable on its own terms. After all, decisions to participate in conflict repeat themselves over time. Contributing to improvement in decisionmaking is thus beneficial. Without (or only with impaired) information, decisionmaking becomes ad hoc and may be driven more by media and public opinion than by evidence.

The question of transparency brought up by the difficulty of estimating conflict costs is similarly two-sided. From a campaigning perspective, politicians like to argue in favor of improved transparency, even as political economy models would argue that there is no inherent benefit to openness for the individual politician. ${ }^{4}$ After all, increased transparency is associated with increased scrutiny of politicians' job performance, which is generally a negative rather than a positive factor. Conversely, politicians associated with opposition parties may find that an evidence-based critique of a government's policy generates more traction with voters than critique based solely on insinuations and expectations.

In contrast to these (perhaps cynical) views concerning the role of politicians, one may take a more practical view: Because it is easy to criticize a government when it is not clear what are the exact costs and benefits of its policies, increased transparency makes it easier for government to defend them. If a particular military campaign has cost a government, say, $€ 10$ billion, this may be a price worth paying. But if the price is unknown, critics can use this as an argument against a military engagement. (For proper comparison, however, the analysis of the benefits of a military engagement must be of similar quality and be as trustworthy as the analysis of its costs.)

\section{The general public}

The public's role as the ultimate paymaster of war is not trivial. Unfortunately, presently it is difficult for individual voters to obtain the information necessary to judge policies as they are being implemented. If such information were available, voters could better monitor and reward or punish policymakers. Such power is a necessary part in a well-functioning democracy. It is the public's right to have this information, and the public should insist on being provided with it.

Yet the public must also understand certain limitations of such research. Even with perfect transparency, part of the analysis will always still be based on estimations. For example, the cost of an ongoing conflict includes estimations of its future expenses, and these will depend on the development of the specific conflict under scrutiny. Further, benefits of military engagements can exist but may not be quantifiable to the same degree, detail, and precision as conflict costs. For example, many countries' marginal contribution to the success of a military engagement is practically zero as the participation of yet another small country in a larger, coalition-based war such as in Afghanistan, Iraq, or Libya will not influence its ultimate outcome. The benefits of participation for a small country are rather intangible, possibly including categories such as the goodwill on behalf of major powers such as the United States of America.

\section{Literature on conflict cost analysis}

The budgetary cost of any specific conflict is typically studied using an accounting approach. This approach faces various challenges in data availability and government transparency. This is not to be confused with the study of the overall cost of conflict, where counterfactual analysis is used to estimate the difference between the economic state of a country involved in war and one that is not. An example of this literature includes Abadie and Gardeazabal, who look at the Basque conflict in Spain. Using different approaches, Collier, Brauer and Tepper-Marlin, and de Groot, Bozzoli, and Brück all find that the global economy would benefit significantly from the absence of conflict. ${ }^{5}$

\section{Overall military expenditure}

The literature on military expenditure is broad and diverse. The major player in this field is SIPRI whose yearbooks provide the most objective and internationally comparable data on military expenditure. Even for SIPRI, however, it is a challenge to provide consistent, comparable data for all countries in the world, and for some major countries only rough expenditure estimates are available. ${ }^{6}$ A large part of the literature addresses the United States only. This is not surprising as the U.S. accounts for about 43 percent of world military expenditure. Other work looks at the impact of military expenditure on national economies, such as on economic growth, or at the probability of a conflict being stimulated by military expenditure, or its relation to income or other forms of inequality, or its role in war recurrence in postwar societies.

The important distinction between these works and studies that look at the cost of specific wars is that the former generally do not attribute military expenditure to specific conflicts. As a result, while data on military expenditure are useful as inputs for certain types of conflict analyses, this literature does not answer questions regarding the cost of any specific conflict.

Cost of war

Measuring the cost of a specific conflict is not the same as measuring military expenditure. One important distinction is that one must separate the share of military expenditure going to a particular conflict from its nonconflict share. Another is that not all of the conflict costs are reflected in military expenditure. For example, societal consequences resulting from wartime mortality would certainly be a cost of conflict but are not ordinarily considered a military expense. As a result, analyses of conflict costs differ from analyses of military expenditure.

A range of studies have used primarily accounting methodologies to analyze the cost of specific wars. For example, William Nordhaus assembled data on the costs to the United States of a number of its wars. (Unless otherwise indicated, this section 
uses base year 2002 dollars.) Thus, the American civil war supposedly cost about USD62 billion (104 percent of annual GDP), WWII about USD2,900 billion (130 percent), and the Vietnam war about USD500 billion (12 percent). The first Gulf war in 1990/91 was “cheap” at only USD76 billion (1 percent). ${ }^{8}$

A particularly well-studied example is the U.S.-led invasion of Iraq in 2003. Nordhaus made an ex ante projection of the likely cost of this invasion. Recognizing that his numbers are uncertain due to the unclear nature of both the costs and the conflict scenarios, he arrives at figures in the range of USD100 billion to USD1,900 billion. He includes military spending per se as well as costs related to occupation, reconstruction, humanitarian assistance, the likely impact on the macroeconomic environment, and on the crude oil and associated markets. At a similarly early stage, Davis, Murphy, and Topel projected a cost of USD103-872 billion (base year 2003), including channels such as direct military expenditure, occupation, fatalities, reconstruction, and humanitarian assistance. Although most ex ante estimates by the American government itself are not in the public domain, a study by the House Budget Committee's Democratic Staff expected the total cost of the war to lie between USD48-93 billion. ${ }^{9}$

With the start of the Iraq war, additional estimates were made. For the period 2003-2015, Wallsten and Kosec expected the cost of the war in Iraq for the United States to be at most USD672 billion. They also note that for this period, the U.S. would avoid costs of about USD125 billion (both in base year 2000 dollars). Probably the most famous forecast of the total U.S. cost of the Iraq war is Stiglitz and Bilmes' number of USD3 trillion (base year 2008). Edwards provides a thorough overview of the existing literature and discusses some of the most poignant problems. He focuses on the difficulty of including all cost channels and properly identifying all of the healthcare and veterans-related costs. Orszag makes a particularly succinct point about the difficulties of separating the costs of ageing and wartime service. ${ }^{10}$

The next section proposes and discusses a method for analyzing the cost of specific military engagements. Tested for the case of Germany's involvement in the Afghan conflict, it can be of use to those who would like to perform a similar analysis. ${ }^{11}$ For the case of Afghanistan, a rather large difference emerged between what the German government presented as the cost of the involvement and the true economic cost. In fact, the cost was estimated at about two to three times the size of the government's claim.

\section{A model for budgetary conflict cost analysis}

This section, as is the whole article, is based on the experience of researching Germany's involvement in Afghanistan, itself a broadening of the work of Bilmes and Stiglitz. The analysis concerns itself with so-called nonterritorial conflict, that is, conflict taking place outside a country's own territory. Examples include the wars in Afghanistan and Iraq, but also the Vietnam war and, from a U.S. perspective, even the second world war. This type of war differentiates itself from other conflicts, such as civil or international conflicts, by not having a strong direct impact on the domestic economy for instance through capital destruction. Often, this concerns economically advanced countries that enter foreign conflicts on the basis of an international coalition. $^{12}$

The decision of what factors to include in a conflict cost analysis and what factors to ignore is driven by (1) practicality and data availability, (2) logic, and (3) the level of transparency of the government in question. With respect to the first point, for an analysis to be feasible, one must have reasonable expectations about the level of detail that can be expected. While some data may be easily available, many are not. With respect to the second point, it is crucial to consider the whole spectrum of possible cost channels. After all, the whole point is to identify which channels there are and how these may be included in an analysis. Finally, regarding transparency, it should be noted that governments are not eager to have anyone scrutinizing their expenditure. They have strong incentives to obscure their true spending, particularly during elections or when a military engagement does not have much popular support. One may naively expect democratic governments in developed countries to value accountability and transparency, but this is rarely the case in practice.

Using prior war years, it is possible to arrive at realistic estimates of different cost categories on a per soldier basis. It is the responsibility of the researcher to develop a set of realistic scenarios for future war years, and this includes withdrawal dates and troop and fighting intensities (and thus injury and death rates). Using assumed troop intensities for the future, one can use prior-year per soldier estimates to create approximate future war budgets. The design of realistic scenarios is very important. One way to overcome criticism is by using alternative scenarios that display the inherent uncertainty involved in military planning.

This section discusses the four main cost channels separately. First, the costs that accrue to the defense department are discussed, followed by the costs borne by other government departments. The third subsection addresses the role of war financing, and the fourth looks at costs accruing to the economy at large.

Ministry of Defense

The Ministry of Defense (MoD) probably makes the largest contribution to any particular war. Depending on the size of the conflict and the type of political system, it is likely that a government must either submit a spending bill to parliament beforehand or is accountable to parliament afterwards. In either case, it is necessary to check whether claimed expenses are the true expenses. In the case of Germany, only the budget appraisals were publicly available, and it could not always be verified that claimed and true expenditures matched within the various budget categories. ${ }^{13}$ On top of that, often only a limited number of budget categories are included in the spending bills presented to parliament. Generally included in appropriation bills are 
typical costs such as conflict-specific military equipment, wage increases required by deployed military personnel, and deployment costs. (Table 1 summarizes the cost categories discussed in this subsection and their potential data sources.) The most important item that is not necessarily included is the cost of military personnel. The argument for not including basic personnel costs is that the soldiers deployed in war would otherwise have been hired as well. While this is true in the case of short and unexpected conflicts, Brzoska argues that for a long-lasting conflict, soldiers' wages should also be part of the costs attributable to conflict as the base number of soldiers employed is larger than otherwise would be the case. Following Petersohn, the number of soldiers stationed in the war zone must be multiplied by a factor of six to ensure that individual soldiers do not serve more than one tour of duty per six month period and to account for the fact that for each soldier currently on duty, there is one who just returned and one who is about to be deployed. The approximate costs of employment differ greatly by country and any estimation should of course be adapted to the situation at hand. ${ }^{14}$

Next, while the cost of mobilization usually is taken into account, that of demobilizing often is not. As it is difficult to estimate the cost of demobilization from the outside and ex ante, it is useful to look at established examples such as the cost borne by other countries withdrawing under similar circumstances. For the case of the Afghan war, for instance, Verhagen and van Middelkoop estimated that the Dutch withdrawal cost amounted to approximately $€ 229$ million. This can function as a benchmark figure for other countries withdrawing from similar conflicts. ${ }^{15}$

The role of equipment purchases is another factor that is strongly dependent on the local situation. Military purchases made specifically for a particular war should be included in the MoD's war budget, but equipment purchased for another purpose, even if used in the conflict, should probably not be counted. But if equipment is lost during war, its cost must be included, and if equipment depreciates faster in war than it otherwise would, depreciation costs also are part of the war burden. Unfortunately, transparency in regard to equipment purchasing is limited, so rough approximations may be necessary to come up with useful numbers.

Depending on the country's budgetary structure, veterans' benefits may be a large contributor to war costs, even though these costs are only incurred in the future. For the United States, Bilmes and Stiglitz find that the future cost of veteran care (healthcare in particular) contribute a great deal to the cost of a current conflict. For the United States, pensions as well as future healthcare coverage are considered as advantages associated with jobs in its armed forces. That implies that a greater use of military forces also leads to increased future spending. Although this can be a large cost category, it is important to use local legislative sources to analyze what responsibilities the state has toward its veterans: In some cases, states may simply be contributing to private pension plans, which do not incur future uncovered expenditure or may not require specific additional healthcare benefits for veterans.

Related to this, states do bear costs resulting from deaths and injuries. Injury and
Table 1: Summary of conflict-related costs accruing to the Ministry of Defense

\begin{tabular}{|c|c|c|}
\hline Cost category & Possible data source & Notes \\
\hline Appropriations bills & $\begin{array}{l}\text { MoD; Treasury; } \\
\text { Parliament }\end{array}$ & $\begin{array}{l}\text { Values in appropriation } \\
\text { bills are ex ante estimates }\end{array}$ \\
\hline $\begin{array}{l}\text { Ex-post accounting } \\
\text { of appropriations bills }\end{array}$ & $\begin{array}{l}\text { MoD; Government } \\
\text { Accountability Office; } \\
\text { Parliament }\end{array}$ & \\
\hline $\begin{array}{l}\text { Cost of military } \\
\text { personnel }\end{array}$ & Expert views & $\begin{array}{l}\text { Only to be included in } \\
\text { long-running conflicts }\end{array}$ \\
\hline Demobilization & $\begin{array}{l}\text { Expert views; experiences } \\
\text { from other countries }\end{array}$ & Cost accrues in future \\
\hline $\begin{array}{l}\text { Equipment purchase } \\
\text { and depreciation }\end{array}$ & MoD; expert views & $\begin{array}{l}\text { Some will be included } \\
\text { in appropriations bills }\end{array}$ \\
\hline Veterans' benefits & $\begin{array}{l}\text { MoD; legal statutes; expert } \\
\text { views }\end{array}$ & $\begin{array}{l}\text { Cost accrues in future; } \\
\text { can vary among cases }\end{array}$ \\
\hline Deaths and injuries & $\begin{array}{l}\text { MoD; legal statutes; health } \\
\text { care providers }\end{array}$ & $\begin{array}{l}\text { Refers to MoD cost only, } \\
\text { societal/human costs }\end{array}$ \\
\hline
\end{tabular}

death rates in conflict differ widely across conflicts, but also among different types of military engagements. For example, Brück, de Groot, and Schneider find that approximately four percent of German soldiers were injured in Afghanistan, whereas Bilmes and Stiglitz conclude that approximately 40 percent of soldiers return from the battlefield with injuries (including post-traumatic stress disorder). But even between wars, death and injury rates differ a lot. During the Vietnam war, some 60,000 U.S. soldiers were lost, out of a total of 2.6 million, while in Afghanistan some 1,800 U.S. soldiers lost their lives. The human cost of such deaths are difficult to express, but the necessary expenditure associated with them such as widow/er's benefits are matters of government policy. Likely, injuries (particularly those leading to permanent disability) are much more costly from a budgetary point of view, including future costs, and these must also be taken into account. ${ }^{16}$ 
Table 2: Summary of conflict-related costs accruing to non-MoD government offices

$\begin{array}{lll}\text { Cost category } & \text { Possible data source } & \text { Notes } \\ \text { Development cooperation } & \text { Expert views; Treasury } & \begin{array}{l}\text { The inclusion of this } \\ \text { category is highly } \\ \text { situation-dependent }\end{array} \\ \text { Civil deployment } & \begin{array}{l}\text { Expert views; Treasury; } \\ \text { Parliament }\end{array} & \begin{array}{l}\text { Differentiation between } \\ \text { national and international } \\ \text { deployment }\end{array} \\ \text { Security } & \begin{array}{l}\text { Expert views; } \\ \text { Home Affairs }\end{array} & \begin{array}{l}\text { Situation-dependent and } \\ \text { difficult to estimate } \\ \text { exactly }\end{array} \\ \text { International cooperation } & \text { Expert view; Treasury } & \begin{array}{l}\text { Situation-dependent and } \\ \text { difficult to estimate }\end{array}\end{array}$

\section{Other government expenditure}

Underappreciated in the literature on conflict cost analysis are costs associated with departments other than the MoD (see Table 2). Such costs accumulate through various channels, the importance of which depends on the type of war and on country-specific factors. Channels include the effects on development cooperation, civilian deployment (through policing, for example), increased domestic insecurity, direct payments necessary to appease neighboring countries, and increased medical expenses if not already covered by military budgets.

The role of development cooperation and civil deployment of police forces are a well-known way through which inherently military missions can be covered by development budgets. SIPRI's analyses of military expenditure do try to account for this by estimating the share of development and security budgets actually employed by the military, but to do this on a per conflict basis is more challenging. When specific data is unavailable, it may be necessary to make estimations of such costs. It can either be assumed that a conflict country, or its neighbors, requires a percentage increase in the amount of development aid, or that there is an absolute amount of aid required to overcome some of the difficulties in international relations. In any case, the existence of such transfers may not be immediately recognized by governments, even if they do take place.
With regard to security, little information is available. The conflicts in Afghanistan and Iraq were supposed to reduce the occurrence of terrorism and make the world a safer place. However, while terror organizations may have decreased in size, threats made by its members are now directed at all countries involved in the wars. For this reason, it may be reasonable to argue that participation in the Afghan and Iraq conflicts has had negative consequences and thus increased security expenditures. However, items such as increased vigilance at international airports, expansion of intelligence agency workloads, and increased security at public events are difficult to quantify. It is necessary to remember that the sum total of expenditure on the security apparatus is huge, so that even a relatively small increase entails significant costs.

For cost categories that can only be approximated for past years, forecasting future expenditure may be even harder. For example, it is inherently difficult to estimate what the impact of a particular conflict is on the expenditure for domestic security. On the basis of expert views and existing sources, it may be possible to estimate a current annual value. One can then assume a constant per soldier cost basis and use this to calculate future spending.

\section{Financing}

The role of financing government war expenditure is hotly debated. One could argue that the cost of financing is zero since it simply replaces other expenditure or because such costs are already implicitly included in the expenditure items themselves. This would, however, misrepresent the importance of government financing at the national level.

Governments can finance war expenditure through two channels: current or future taxation or expenditure shifting. In the first case, this requires either new or higher taxes, now or later, thus hurting economic growth; in the second case, this involves the transfer of expenditure from nonmilitary to military functions. If the allocation of government funds is ex ante optimal, a move from more to less productive use of funds is implied. For example, if one must reduce expenditure on education in order to finance war, this probably leaves the country worse off. In the case of borrowing, one must pay for an infinite stream of interest payments unless and until the loan principal is paid off. Both can only be done through future taxation. The current debt burden of the United States, to which the Afghan and Iraq wars have contributed significantly, is a case in point.

Unfortunately, governments do not commonly link specific revenue sources directly to specific expenses. For that reason, one intermediate solution can be to assume that war expenditure is financed in the same way as is the overall government's expenditure, usually a split of approximately 90 percent taxation and 10 percent borrowing, say. Under that assumption, it is possible to look at the effect of each of these avenues of financing separately. For convenience, assume that the taxation-financed share of government expenditure crowds out more effective general 
Table 3: Data requirements and possible sources with respect to financing needs

$\begin{array}{lll}\text { Data requirement } & \text { Possible source } \\ \text { Current financing structure } & \text { Ministry of Finance }\end{array}$

Expected future interest rate Expert views; Treasury

Multiplier difference

Expert views

government spending. In this case, the economic impact of government expenditure is less beneficial for the economy in a Keynesian sense. This impact can be quantified by taking the difference of the multiplier on military expenditure and the multiplier on nonmilitary government expenditure. According to Stiglitz and Bilmes, a reasonable estimate for the United States is that this difference is approximately 0.4. In smaller, more open economies, where leakage is greater, the difference may exceed this estimate. One would conclude that for the taxation-based part of financing the expense of war, the economic impact of crowding-out amounts to an additional 40 percent of expenditure. The borrowed part of the expenditure can be treated as future interest payments, with the economic (crowding-out) impact of the repayment taking place at some future time.

The economy at large

The economy as a whole suffers a number of further costs, not reflected in either the government's coffers or through war financing (see Table 4). The largest of these results from the way a war can impact the global economy. The war in Iraq, and possibly this holds for Libya as well, has been argued to have had a significant effect on oil prices and perhaps has entailed significant environmental consequences as well. But an important distinction must be made concerning one's analysis: A researcher interested in the impact of a conflict should include the shock effects that occur through oil prices, but when interested in the impact of a country's participation in a conflict, this effect should only be included if the war would not have taken place in that country's absence. That is, for coalition-based conflicts, the marginal contribution of different countries to the way a conflict develops is often so small that the global economic impact of this conflict is independent of a country's participation. ${ }^{17}$

When global macroeconomic consequences are included, the estimation of what
Table 4: Summary of nonbudgetary costs accruing to the overall economy

$$
\text { Cost category Possible data source Notes }
$$

Global economy (oil prices) Expert views; Only to be included if

international institutions country's conflict

participation was

pivotal

Loss of lives

Expert views; government SVL estimations vary proceedings widely among regions

would have happened to the global economy are not straightforward. After all, it is difficult to determine a counterfactual that does not include the occurrence of a particular conflict. Stiglitz and Bilmes therefore focus only on the oil price. Using the pre-conflict price to estimate the difference between the real and counterfactual prices during the conflict, they estimate the macroeconomic impact of the Iraq conflict.

In addition to this macroeconomic effect which, if included, is likely to be huge, there are other costs. For example, estimating the economic value of the loss of life or loss of productivity through injury is a thorny issue, but must be addressed. Stiglitz and Bilmes use the Statistical Value of Life (SVL) assigned by the Environmental Protection Agency to determine the economic cost of lost lives. Expressed in 2008 dollars, this value comes to USD7.2 million per person. From a European perspective, several studies argue in favor of a remarkably lower SVL, with Belgian, Dutch, and German estimates all ranging between $€ 2$ and $€ 2.4$ million (in 2010 euros). ${ }^{18}$

Further assumptions and challenges

Knowing all the various contributing factors to the total budgetary cost of conflict is a good starting point, but there are a number of further assumptions required to build a model that estimates the total cost of a specific conflict. When it comes to timing, it is crucial that one considers at which moment all the costs discussed occur. This is most easily envisaged as a spreadsheet with which to allocate all costs (in columns) to past and future years (in rows). Using a reasonable discount rate, one can sum up these costs for the current year, where future costs are weighed less than costs that occurred in the past. For example, the costs of withdrawal can be assumed to be fixed for a given deployment, but its Net Present Value (NPV) would depend on the assumptions regarding the timing of withdrawal.

Everything described thus far depends on more or less questionable assumptions, 
Table 5: Example of results from conflict budget analysis (in 2010€)

$\begin{array}{lll}\begin{array}{l}\text { Lower } \\ \text { bound }\end{array} & \begin{array}{l}\text { Point } \\ \text { estimate }\end{array} & \begin{array}{l}\text { Upper } \\ \text { bound }\end{array} \\ & & \\ \text { 18.2B } & 25.5 \mathrm{~B} & 32.8 \mathrm{~B} \\ 25.9 \mathrm{~B} & 36.5 \mathrm{~B} & 47.1 \mathrm{~B} \\ \text { 52.7B } & 72.6 \mathrm{~B} & 92.5 \mathrm{~B}\end{array}$

$\begin{array}{llll}\text { Withdraw 2011 } & 18.2 \mathrm{~B} & 25.5 \mathrm{~B} & 32.8 \mathrm{~B} \\ \text { Withdraw 2014 } & 25.9 \mathrm{~B} & 36.5 \mathrm{~B} & 47.1 \mathrm{~B} \\ \text { Withdraw 2020 } & 52.7 \mathrm{~B} & 72.6 \mathrm{~B} & 92.5 \mathrm{~B}\end{array}$

Source: Brück, de Groot, and Schneider (2011). confidence to each of the categories, it is then straightforward to arrive at lower and upper bounds for the point estimates. It may be advisable to set the lowest level of confidence at 0 percent, thus entirely excluding the least certain items from the analysis.

In this article only the cost of war is discussed, but there may be benefits as well. For example, Wallsten and Kosec argue that by initiating the war in Iraq, the United States saved itself the considerable expense of continuing to enforce the no-fly zone. ${ }^{19}$ Other benefits could be reflected in the oil price, or in the creation of new export markets. For smaller non-pivotal countries in war, one could argue that their participation in a coalition improves international relations. If the United States wants to legitimize a particular military action, and a country's minor contribution can help doing so, this is likely to improve the relation between this country and the United States. One could see the contributions made by some of the coalition partners in Afghanistan in this light. After all, Iceland's 4 troops, Austria's 3, Ukraine's 22 , and Malaysia's 31 are unlikely to have been critical to the overall mission, but the political implications of their support may create leverage for these countries' governments. Such leverage, while hard to quantify, should not be taken lightly.

As an example, the analysis by Brück, de Groot, and Schneider showed that the German involvement in the Afghan war was much costlier than the government publicly acknowledged. ${ }^{20}$ Table 5 is an example of what could come out of other research when performing a similar analysis. It shows the lower bound, point estimate, and upper bound of the Net Present Value (in 2010 euros) of the German participation in the war. Three scenarios are included, one in which troops are immediately withdrawn, a more realistic scenario in which troops are pulled out in 2014, and a full-engagement scenario that envisages a doubling of troop levels and a commitment to stay until 2020. Not shown, but important, is the annual cost associated with the conflict. Whereas the government's appropriation bill asks for approximately $€ 1$ billion, the true cost of a one-year increase in war-length are between $€ 2.5$ and $€ 3$ billion, surely a significant increase.

\section{Conclusion}

This article describes steps necessary for a comprehensive and consistent analysis of the budgetary implications of military engagements. This is an important topic because war-related policies seem generally to be made without proper cost-benefit analysis. Knowing the potential cost of a conflict will enable policymakers to decide in a more objective manner whether a military engagement is worth considering. The path to estimation is littered with difficulties and one should realize that the necessary approximations can be quite imprecise. However, even when an analysis is unable to arrive at precise projected cost figures, it is still worth doing since the associated lack of precision and transparency is in itself an important message to convey. Moreover, voters and the taxpaying public deserve to know if there is a significant lack of transparency with respect to the cost of military engagement.

If future research were able to provide comparable numbers across different participants in similar conflicts (for example, for each of the different coalition forces in the Afghan conflict), it would not only be possible to say which countries fight more effectively, but it would also become possible to estimate the global budgetary cost of a specific conflict consisting of a large range of actors. Similarly, if different conflicts could be analyzed using the same methodology, it would be interesting to look at what has happened over time: Did the conduct of war become more expensive or did it become cheaper?

Notes

Olaf J. de Groot is a researcher at the German Institute of Economic Research, Department for Development and Security, Berlin, Germany. He may be reached at <odegroot@diw.de>. The author is grateful for comments by Jurgen Brauer, J. Paul Dunne, and others who commented on drafts. Research and writing of this article has been supported by the Chair on Markets and Industrial Policy, financed by ISDEFE and hosted by the Barcelona Institute of Economics, University of Barcelona. The views and opinions expressed here are the sole responsibility of the author and do not necessarily reflect the view of the supporting institutions.

1. The former: See, e.g., Collier (1999); Brauer and Tepper-Marlin (2010); de Groot (2011); Bozzoli, Brück, and de Groot (2012). The latter: Exceptions include, e.g., Nordhaus (2002); Davis, Murphy, and Topel (2009); Edwards (2010). Note that in the present article the words "conflict” and "war" are used interchangeably.

2. Bilmes and Stiglitz (2006); Stiglitz and Bilmes (2008); SIPRI (2011).

3. Stiglitz and Bilmes (2008); Brück, de Groot, and Schneider (2010). 
(C) www.epsjournal.org.uk - Vol. 7, No. 2 (2012)

4. Persson and Tabellini (2002); Alt and Lassen (2006).

5. Abadie and Gardeazabal (2003); Collier (1999); Brauer and Tepper-Marlin (2010); de Groot, Bozzoli, and Brück (2011).

6. Foster, Holleman, and McChesney (2008) point out that there is a large difference between the actual military expenditure and officially recognized expenditure. Brzoska (1981) and others argue that even the available data on military expenditure may not be trustworthy.

7. U.S. military expenditure: SIPRI (2011). Economic growth: See, e.g., Dunne, Smith, and Willenbockel (2005); Smyth and Narayan (2009).War probability: Murshed and Mamoon (2010). Inequality: Lin and Ali (2009). War recurrence: Collier and Hoeffler (2004).

8. Nordhaus (2002).

9. Nordhaus (2002); Davis, Murphy, and Topel (2009). [The Davis, Murply, and Topel study was carried out in 2003 but only published in 2009.] Public domain: See Nordhaus (2002). House Budget Committee’s Democratic Staff (2002).

10. Wallsten and Kosec (2005); Stiglitz and Bilmes (2008); Edwards (2010); Orszag (2008).

11. Brück, de Groot, and Schneider (2011).

12. Nonterritorial conflict: de Groot (2011).

13. But for at least one year evidence was uncovered to show that the true expenditure exceeded the appropriations bill by some 25 percent.

14. Brzoska (2007); Petersohn (2008).

15. Verhagen and van Middelkoop (2010).

16. Brück, de Groot, and Schneider (2011); Stiglitz and Bilmes (2008). Vietnam war losses: (VVMF, 2011). Afghan losses: Defenselink (2011).

17. Oil prices: Stiglitz and Bilmes (2008). Environment: Reuveny, Mihalache-O’Keef, and Li (2010). Marginal contribution: Brück, de Groot, and Schneider (2011).
18. European estimates: de Brabander and Vereeck (2007); Raad voor de Volksgezondheid en Zorg (2006); Spengler (2004).

19. Wallsten and Kosec (2005).

20. Brück, de Groot, and Schneider (2010; 2011).

\section{References}

Abadie, A. and J. Gardeazabal. 2003. "The Economic Costs of Conflict: A Case Study of the Basque Country.” American Economic Review. Vol. 93, No. 1, pp. 113-132.

Alt, J.E. and D.D. Lassen. 2006. "Fiscal Transparency, Political Parties, and Debt in OECD Countries.” European Economic Review. Vol. 50, No. 6, pp.1403-1439.

Bilmes, L. and J. Stiglitz. 2006. "The Economic Costs of the Iraq War: An Appraisa Three Years After the Beginning of the Conflict.” Boston: NBER Working Papers No. 12054.

Bozzoli, C., T. Brück, and O.J. de Groot. 2012. "How Many Bucks in a Bang: On the Estimation of the Economic Costs of Conflict,” pp. 252-274 in M. Garfinkel and S. Skaperdas, eds. Oxford Handbook of the Economics of Peace and Conflict Oxford, UK: Oxford University Press.

Brauer, J. and J. Tepper Marlin. 2010. "A Method to Compute a Peace Gross World Product by Country and by Economic Sector,” pp. 13-30 in B.E. Goldsmith and J. Brauer, eds. Economics of War and Peace: Economic, Legal, and Political Perspectives. Bingley, UK: Emerald Group.

Brück, T., O.J. de Groot, and F. Schneider. 2010. "Eine erste Schätzung der wirtschaftlichen Kosten der deutschen Beteiligung am Krieg in Afghanistan.” Berlin: DIW Wochenberichte. Vol. 77, No. 21.

Brück, T., O.J. de Groot, and F. Schneider. 2011. "The Costs of the German Involvement in the War in Afghanistan.” Journal of Peace Research. Vol. 48, No. 6, pp. 793-805.

Brzoska, M. 1981. “The Reporting of Military Expenditures.” Journal of Peace Research. Vol. 18, No. 3, pp. 261-275.

Brzoska, M. 2007. "Sind militärische Interventionen ihr Geld wert? Zur Notwendigkeit begleitender Kosten- und Nutzenanalysen,” pp. 75-85 in B Schoch, A. Heinemann-Grüder, J. Hippler, M. Weingardt, and R. Mutz, eds. Friedensgutachten 2007. Berlin: LIT-Verlag.

Collier, P. 1999. “On the Economic Consequences of Civil War.” Oxford Economic Papers. Vol. 51, pp. 168-183.

Collier, P. and A. Hoeffler. 2004. "Military Expenditure in Post-Conflict Societies." Oxford, UK: CSAE Working Papers No. 2004-13.

Davis, S.J., K.M. Murphy, and R.H. Topel. 2009. "War in Iraq versus Containment,” 
pp. 203-270 in G.D. Hess, ed. Guns and Butter: The Economic Causes and Consequences of Conflict. Cambridge, MA: MIT Press.

De Brabander, B. and L. Vereeck. 2007. "Valuing the Prevention of Road Accidents in Belgium.” Transport Reviews. Vol. 27, No. 6, pp. 715-732.

Defenselink 2011. “Defenselink Casualty Report.” http://www.defense.gov/news/ casualty.pdf [accessed 24 October 2011].

De Groot, O.J. 2011. "A Methodology for the Calculation of the Global Economic Costs of Conflict,” in R. Caruso, ed. Contributions to Peace Science and Peace Economics. Bingley, UK: Emerald Publishing.

De Groot, O.J., C. Bozzoli, and T. Brück. 2011. “The Global Economic Costs of Violent Conflict.” Mimeo. Berlin: DIW.

Dunne, J.P., R. Smith, and D. Willenbockel. 2005. "Models of Military Expenditure and Growth: A Critical Review.” Defence and Peace Economics. Vol. 16, No. 6 , pp. 449-461.

Edwards, R.D. 2010. “A Review of War Costs in Iraq and Afghanistan.” Boston: NBER Working Papers No. 16163.

Foster, J.B, H. Holleman, and R.W. McChesney. 2008. “The U.S. Imperial Triangle and Military Spending.” Monthly Review. Vol. 60, No. 5, pp. 1-19.

House Budget Committee, Democratic Staff. 2002. "Assessing the Cost of Military Action against Iraq: Using Desert Shield/Desert Storm as a Basis for Estimates.” http://budget.house.gov/analyses/spending/iraqi_cost_report.pdf.

Lin, E.S. and H.E. Ali. 2009. "Military Spending and Inequality: Panel Granger Causality Test.” Journal of Peace Research. Vol. 46, No. 5, pp. 671-685.

Murshed, S.M. and D. Mamoon. 2010. "Not Loving Thy Neighbour as Thyself: Trade, Democracy and Military Expenditure Explanations Underlying the India-Pakistan Rivalry.” Journal of Peace Research. Vol. 47, No. 4, pp. 463-476.

Nordhaus, W.D. 2002. “The Economic Consequences of a War in Iraq.” Boston: NBER Working Paper No. W9361.

Orszag, P.R. 2008. "The Cost of the War: A Comment on Stiglitz-Bilmes.” CBO Director's Blog. http://cboblog.cbo.gov.

Persson, T. and G. Tabellini. 2002. Political Economics: Explaining Economic Policy. Cambridge, MA: MIT Press.

Petersohn, U. 2008. "Outsourcing the Big Stick: The Consequences of Using Private Military Companies.” Weatherhead Center for International Affairs. Working Paper Series No. 08-0129:73.

Raad voor de Volksgezondheid en Zorg. 2006. “Zinnige en Duurzame Zorg.” [Useful and Lasting Care.] Policy Advice to Ministry of Health. http://rvz.net/uploads/docs/Advies_-_Zinnige_en_duurzame_zorg.pdf.

Reuveny, R., A.S. Mihalache-O’Keef, and Q. Li. 2010. “The Effect of Warfare on the Environment.” Journal of Peace Research. Vol. 47, No. 6, pp. 749-761.

SIPRI. 2011. SIPRI Yearbook 2011: Armaments, Disarmament and International Security. Oxford, UK: Oxford University Press.
Smyth, R. and P.K. Narayan. 2009. "A Panel Data Analysis of the Military Expenditure-External Debt Nexus: Evidence from Six Middle Eastern Countries.” Journal of Peace Research. Vol. 46, No. 2, pp. 235-250.

Spengler, H. 2004. "Kompensatorische Lohndifferenziale und der Wert eines statistischen Lebens in Deutschland.” [Compensatory Wage Differences and the Value of a Statistical Life in Germany]. Darmstadt: Darmstadt Discussion Papers in Economics 133 http://www.download.tu-darmstadt.de/wi/vwl/ddpie/ddpie _133.pdf.

Stiglitz, J.E. and L.J. Bilmes. 2008. The Three Trillion Dollar War: The True Cost of the Iraq Conflict. London: Penguine Books.

Verhagen, M. and. E. van Middelkoop. 2010. "Kamerbrief inzake stand van zaken Afghanistan. [Parliamentary Letter Regarding the Current State of Affairs in Afghanistan]. Official Correspondence of Dutch Parliament. http://www.rijksoverheid.nl/ministeries/bz/documenten-en-publicaties/kamerst ukken/2010/09/28/kamerbrief-inzake-stand-van-zaken-afghanistan.html.

VVMF. 2011. "Five Names to be Added to the Vietnam Veterans Memorial.”VVMF Press Release: http://www.vvmf.org/702.cfm.

Wallsten, S. and K. Kosec. 2005. "The Economic Costs of the War in Iraq." AEI-Brookings Joint Center Working Paper No. 05-19. http://papers.ssrn.com/sol3/papers.cfm?abstract_id=848408. 